\title{
GROWTH AND PRODUCTIVITY OF EGGPLANT AS AFFECTED BY PINK PIGMENTED FACULTATIVE METHYLOTROPHIC BACTERIA
}

\author{
Abd El-Salam 1, H.M., Abou El-Yazied', A., Abd El-Gawad', H.G. \\ and Abdelhafez ${ }^{2}$, A.A. \\ 1. Horticulture Dept., Fac. of Agric., Ain Shams Univ., P.O. Box 68, Hadyek Shoubra11241, \\ Cairo, Egypt \\ 2. Microbiology Dept., Fac. of Agric., Ain Shams Univ., P.O. Box 68, Hadyek Shoubra11241, \\ Cairo, Egypt
}

*Corresponding author: hossam1979@hotmail.com

Received 15 October, 2018,

Accepted 1 December, 201

\begin{abstract}
The present study was suggested as an attempt to investigate the effects of Pink Pigmented Facultative Methylotrophic Bacteria (PPFM) dipping and foliar spray on vegetative growth and yield of eggplant (Solanum melongena L.). Field experiments were carried out during the summer seasons of 2014 and 2015 at the Experimental Farm, Faculty of Agriculture, Ain Shams University. The vegetative growth of eggplant responded positively to dipping seedlings in PPFM which gave the highest values of growth parameters, i.e. number of leaves per plant, leaf area, nitrogen \& potassium concentration in leaf and total protein in fruit, in the two seasons as compared with control (dipping in water). The application of PPFM as foliar spray, increased significantly plant growth (plant length, leaf number, potassium concentration in leaf, vitamin "C" in fruit and total yield per plant) in the two seasons as compared with the other studied foliar application treatments. The interaction between dipping seedlings in PPFM and PPFM foliar spray with all concentrations gave synergistic effects on growth parameters and yield components of eggplant, during the two growing seasons as compared with either individual foliar application or control plants.
\end{abstract}

Keywords: Eggplant, PPFM, Foliar spray, Dipping, Growth, Yield

\section{INTRODUCTION}

In Egypt, eggplant is considered as one of the most important crops grown in the summer season. The varieties of Solanum melongena L. show a wide range of fruit shapes and colors, ranging from oval or egg-shaped to long club-shaped; and from white, yellow, green through degrees of purple pigmentation to almost black. Eggplant fruits contain a considerable amount of carbohydrates, proteins and some minerals and it's known for being low in calories and having a mineral composition beneficial for human health. They are also a rich source of potassium, magnesium, calcium and iron. The hybrids of eggplant have many advantages compared with open-pollinated cultivars in terms of yield and disease resistance. The yield depends upon several production factors. Among these proper, balanced nutrition plays a significant role.

Pink pigmented facultative methylotrophic bacteria (PPFM), ubiquitous in nature and frequently reported on various plant species, are a substantial part of the aerobic, heterotrophic microflora of the surfaces of young leaves (Meena et al 2012). They are capable of growing on $\mathrm{C}_{1}$ compounds such as formate, formaldehyde and methanol in addition to $\mathrm{C}_{2}-\mathrm{C}_{4}$ compounds (Lidstrom, 2001 and Iguchi et al 2015).

Moreover, they are able to produce plant growth regulators such as cytokinins and auxins (Omer et al 2004 and Nadali et al 2010) which affect plant growth and different physiological processes. The PPFM can also, induce systemic re- 
sistance against diseases (Madhaiyan et al 2004) and degrade a widely range of highly toxic compounds and tolerate heavy metals (Jahan et al 2013). Methanol is considered a natural product of plant metabolism, all plant tissues emit methanol (Gout et al 2000) especially during early stages of leaf expansion (Fall, and Benson, 1996). Some of this methanol is rapidly oxidized in the presence of light to water and $\mathrm{CO}_{2}$ (Galbally and Kirstine, 2002). Generation of $\mathrm{CO}_{2}$ from methanol can also occur by PPFM (Lee et al 2006 and McTaggart, et al 2015). Increasing $\mathrm{CO}_{2}$ concentration inside stomata led to accelerate the rate of photosynthesis and decrease the rate of photorespiration in $\mathrm{C}_{3}$ plants (Ramirez et al 2006) because the competition between $\mathrm{CO}_{2}$ and $\mathrm{O}_{2}$ for RuBisco enzyme (the enzyme responsible for reducing $\mathrm{CO}_{2}$ and synthesis of carbohydrates during photosynthesis in $\mathrm{C}_{3}$ plants).

Therefore, the objective of this study was to investigate the effect of foliar spray with PPFM and dipping PPFM on vegetative growth, yield and quality of eggplant.

\section{MATERIALS AND METHODS}

Field experiments were carried out during the summer seasons of 2014 and 2015 under open field conditions in the silt soil, at the Experimental Farm, Faculty of Agriculture, Ain Shams University, to study the effect of Pink Pigmented Facultative Methylotrophic Bacteria (PPFM) as dipping seedlings or as foliar spray on vegetative growth and yield of eggplant (Solanum melongena L.).

\section{The experimental design and treatments}

Seeds of eggplant cultivar Soma are produced by Syngenta; 35 days old seedlings were sown on 14 of May during 2014 and 2015 seasons. The area of the experimental is divided into three plots, the dimensions of each plot were 19.5 meters in length, 3 meters in width, each plot was $58.5 \mathrm{~m}^{2}$ consisted of 26 rows; each row was $3 \mathrm{~m}$ length. The plant distance was $0.6 \mathrm{~m}$ apart on one side of ridge. Thus, each plot had 130 plants.

\section{The experiment layout}

This experiment was laid out in a split plot design with three replicates. Dipping seedlings applications were assigned in the main plots, whereas foliar spray treatments was distributed in the sub plots.

The experiment included five treatments as follows

1. Inoculation the Rhizosphere

i. Untreated control; without addition $\left(\mathrm{T}_{1}\right)$.

ii. PPFM dipping; The PPFMs vaccine is added with eggplant seedlings immediately before planting and repeated after 30 days of planting the seedlings around the crown area (20 liters /fed). ( $\left.T_{2}\right)$

\section{Foliar spray}

i. Untreated control; (spraying with tap water). $\left(\mathrm{T}_{3}\right)$

ii. Sprayed PPFM Media on the eggplant / canes without a cell-free vaccine (after centrifugation). ( $\left.T_{4}\right)$

iii. Sprayed PPFMs. $\left(T_{5}\right)$

Sprinkling after 30, 60, 90 days of planting seedlings (20 liters / fed). Preparation of the bacterial vaccine in the Unit of Biological Fertilization Faculty of Agriculture - Ain Shams University.

\section{Agricultural practices}

Agricultural management, disease and pest control programs were followed according to the recommendations of the Egyptian Ministry of Agriculture and Land reclamation.

\section{Studied characteristics}

\section{Vegetative growth characteristics}

Representative samples of nine plants from each experimental plot were randomly chosen after 45,75 and 105 days from transplanting in the two seasons and the following data were recorded: plant length, stem diameter, number of branches per plant, leaf area per plant, number of leaves per plant, leaf and stem fresh and dry weight (A.O.A.C., 2000). Leaf chlorophyll reading (SPAD) was determined using, Minolta SPAD-502, (Minolta Company, Japan), the recently full expanded fourth leaf from the plant top as relation between unit area and leaf fresh weight (Koller, 1972).

Leaf area $\left(\mathrm{cm}^{2}\right)=\frac{\text { Disk area } \times \text { No.Disks } x \text { Leaf f.w }}{\text { Disk f.w }}$ 


\section{Chemical characteristics}

Total nitrogen, phosphorus and potassium were determined in the digested dry matter of plant foliage according to the methods described by Brown and Lilliland (1946), respectively.

Total protein $(\mathbf{g} / \mathbf{1 0 0} \mathrm{g} \mathrm{DW})$ in fruit was calculated by using the conversion factor $(\mathrm{N} \times 6.25)$ as described by Pregl (1945).

Total carbohydrates in fruit was determined colorimetrically according to method described by James (1995).

L ascorbic acid (V.C.) in fruit was determined by using 2, 6-dichlorophenol indophenols titration method as described by A.O.A.C (2000).

\section{Yield characteristics}

Eggplant fruits were harvested every 4 days. Total yield per plant and feddan were recorded.

\section{Statistical analysis}

Data of the two seasons were arranged and statistically analyzed using $M$ static (M.S.). The comparison among means of the different treatments was determined, as illustrated by Snedecor and Cochran (1982) and means were compared by Duncan multiple range test (Waller and Duncan, 1969).

\section{RESULTS AND DISCUSSION}

\section{Vegetative characteristics}

Data presented in Table (1) show the influence of dipping seedlings in PPFM and foliar spray on vegetative characteristics (plant length, leaf area per plant, number of leaves per plant and leaf chlorophyll content) of eggplant in the two seasons (2014 and 2015).

\section{Plant length}

Dipping the seedlings in PPFM generally, gave the tallest plants as compared with the control (not dipping) in the first season and there was no significant change in the second season. This result may be attributed to the importance of PPFM for growth.

Table 1. Effect of pink pigmented facultative methylotrophic (PPFM) bacteria on plant length, leaf area per plant, number of leaves per plant and leaf chlorophyll content of eggplant, in the two seasons (2014 and 2015)

\begin{tabular}{|c|c|c|c|c|c|c|}
\hline Treatments & Control & PPFM dipping & Mean & Control & PPFM dipping & Mean \\
\hline & \multicolumn{3}{|c|}{-----------1 ${ }^{\text {st }}$ season----------- } & \multicolumn{3}{|c|}{-------------2 ${ }^{\text {nd }}$ season----------- } \\
\hline \multicolumn{7}{|c|}{ Plant length $(\mathrm{cm})$} \\
\hline Control & $62.85 \mathrm{~b}$ & $60.11 \mathrm{bc}$ & $61.48 \mathrm{~B}$ & $73.56 \mathrm{a}$ & $68.04 \mathrm{~b}$ & $70.8 \mathrm{~B}$ \\
\hline PPFM Media foliar & $58.35 \mathrm{~cd}$ & $62.1 \mathrm{~b}$ & $60.23 \mathrm{~B}$ & $70.56 a b$ & $65.5 \mathrm{~b}$ & $68.03 \mathrm{~B}$ \\
\hline PPFM foliar & $55.73 \mathrm{~d}$ & $74.57 \mathrm{a}$ & $65.15 \mathrm{~A}$ & $74.81 \mathrm{a}$ & $75 \mathrm{a}$ & $74.9 \mathrm{~A}$ \\
\hline Mean & $58.98 \mathrm{~B}$ & $65.59 \mathrm{~A}$ & --------- & $72.97 \mathrm{~A}$ & $69.51 \mathrm{~A}$ & ---------- \\
\hline \multicolumn{7}{|c|}{ Leaf area per plant $\left(\mathrm{cm}^{2}\right)$} \\
\hline Control & $36.78 \mathrm{~b}$ & $37.86 \mathrm{~b}$ & 37.32 B & $38.92 b$ & $43.77 \mathrm{ab}$ & 41.34 A \\
\hline PPFM Media foliar & $33 \mathrm{~b}$ & $37.36 \mathrm{~b}$ & $35.18 \mathrm{~B}$ & $37.29 \mathrm{~b}$ & $47.65 \mathrm{a}$ & 42.47 A \\
\hline PPFM foliar & $33.92 b$ & $66.16 \mathrm{a}$ & $50.04 \mathrm{~A}$ & $\begin{array}{c}40.04 \\
a b\end{array}$ & $40.58 \mathrm{ab}$ & 40.31 A \\
\hline Mean & $34.57 \mathrm{~B}$ & $47.13 \mathrm{~A}$ & ---------- & $38.75 \mathrm{~B}$ & $44 \mathrm{~A}$ & ---------- \\
\hline \multicolumn{7}{|c|}{ Number of leaves per plant } \\
\hline Control & $92.67 \mathrm{~b}$ & $63.33 \mathrm{~d}$ & $78 \mathrm{~B}$ & $87 \mathrm{~b}$ & $81.33 \mathrm{bc}$ & 84.17 B \\
\hline PPFM Media foliar & $81.67 \mathrm{c}$ & $89.67 \mathrm{~b}$ & $85.67 \mathrm{~A}$ & $70.56 \mathrm{c}$ & $75 \mathrm{c}$ & $72.78 \mathrm{C}$ \\
\hline PPFM foliar & $68.33 \mathrm{~d}$ & $104 \mathrm{a}$ & $86.17 \mathrm{~A}$ & $109.33 a$ & $111.11 \mathrm{a}$ & 110.22 A \\
\hline Mean & $80.89 \mathrm{~B}$ & $85.67 \mathrm{~A}$ & -------- & 83.3 B & $92.48 \mathrm{~A}$ & --------- \\
\hline \multicolumn{7}{|c|}{ Leaf chlorophyll reading (SPAD) } \\
\hline Control & $46.6 \mathrm{~b}$ & $49.48 \mathrm{ab}$ & $48.04 \mathrm{~B}$ & $57.64 \mathrm{a}$ & $58.26 \mathrm{a}$ & $57.95 \mathrm{~A}$ \\
\hline PPFM Media foliar & $49.27 \mathrm{ab}$ & $48.72 \mathrm{ab}$ & 48.99 AB & $56.92 \mathrm{a}$ & $58.52 \mathrm{a}$ & 57.72 A \\
\hline PPFM foliar & $52.19 \mathrm{a}$ & $51.12 \mathrm{ab}$ & $51.65 \mathrm{~A}$ & $58.03 \mathrm{a}$ & $57.89 \mathrm{a}$ & $57.96 \mathrm{~A}$ \\
\hline Mean & 49.35 A & 49.77 A & ---------- & $57.53 \mathrm{~A}$ & $58.22 \mathrm{~A}$ & ---------- \\
\hline
\end{tabular}

Means followed by different letters are significantly different at $\mathrm{P} \leq 0.5$ level; Duncan's multiple range test. 
Regarding the effect of foliar spray, the plant tested varied significantly in plant length, PPFM foliar spray induced highest values of plant length compared with PPFM media foliar spray in both seasons.

The interaction between dipping seedlings in PPFM and PPFM foliar spray produced the highest plant length compared to other combination treatments in both seasons.

These increments may be necessary to improve the vegetative growth of plants because malondyaldehyde (MDA) was concentrated in the meristematic cells and concomitant to cell division (Mène-Saffranè et al 2007 and Schmid-Siegert et al 2012).

\section{Leaf area per plant}

Dipping seedlings in PPFM generally, gave the highest leaf area as compared with the control (not dipping) in the first season and there was no significant change in both seasons.

The effect of foliar spray on the tested plants varied significantly in leaf area, PPFM foliar spray gave the highest values of leaf area compared with the other studied foliar spray in first season but insignificant effect was induced by all foliar spray tested treatments in second season.

The interaction between dipping seedlings with PPFM and PPFM foliar spray caused the highest leaf area than the other combination treatments in the first season but the interaction between dipping seedlings with PPFM and PPFM media foliar spray produced the highest leaf area compared to the other treatments in second season. The obtained results completely agree with the point of view which were reported by Radha et al (2009).

\section{Number of leaves per plant}

Dipping the seedlings in PPFM, gave the highest number of leaves per plants as compared with the control (not dipping) in both seasons.

The plants tested with foliar spray were varied significantly in number of leaves per plant, PPFM foliar spray gave the highest values of leaf number compared with the other studied foliar spray in both seasons.

The interaction between dipping seedlings in PPFM and PPFM foliar spray produced the highest values of leaf number than the other combination treatments in both seasons. In the current study, this effect could be explained by that, PPFM have the ability to produce some growth regulators including auxins and cytokinins (Lee et al 2006 and Nadali et al 2010).

\section{Leaf chlorophyll content}

Dipping the seedlings in PPFM generally caused insignificant effect with all tested treatments in both seasons.

Regarding the effect of foliar spray, the various tested varied significantly in leaf chlorophyll content, PPFM foliar spray gave the highest values of total chlorophyll content of leaf compared with the other studied foliar spray in first season but insignificant effect was observed with all foliar spray tested treatments in second season.

The interaction between control (not dipping seedlings with PPFM) and PPFM foliar spray produced the highest values of leaf chlorophyll reading than the other combination treatments in first season but the interaction with tested treatments in the second season is insignificant.

\section{Leaf Chemical Components}

Data presented in Table (2) show the influence of dipping seedlings with PPFM and foliar spray on chemical characteristics (nitrogen, phosphorus and potassium concentration) in leaf of eggplant in the two seasons (2014 and 2015).

\section{Nitrogen concentration in leaf}

Dipping the seedlings with PPFM generally, gave the highest nitrogen concentration as compared with the control (not dipping).

The effect of foliar spray and the interaction with all tested treatments on nitrogen concentration was found to be insignificant.

\section{Phosphorus concentration in leaf}

Dipping the seedlings with PPFM generally has insignificant effect with all tested treatments. In addition, the effect of foliar spray and the interaction with all tested treatments on phosphorus concentration were shown to be insignificant. 
Table 2. Effect of pink pigmented facultative methylotrophic (PPFM) bacteria on nitrogen, phosphorus and potassium \% in leaf of eggplant, in two seasons $(2014 / 2015)$

\begin{tabular}{|c|c|c|c|c|c|c|}
\hline Treatments & Control & $\begin{array}{c}\text { PPFM } \\
\text { dipping }\end{array}$ & Mean & Control & $\begin{array}{l}\text { PPFM } \\
\text { dipping }\end{array}$ & Mean \\
\hline & \multicolumn{3}{|c|}{------1 ${ }^{\text {st }}$ season--------- } & \multicolumn{3}{|c|}{---------2 ${ }^{\text {nd }}$ season---------- } \\
\hline \multicolumn{7}{|c|}{ Nitrogen \% } \\
\hline Control & $5.502 \mathrm{a}$ & $5.400 \mathrm{a}$ & $5.451 \mathrm{~A}$ & $5.251 \mathrm{a}$ & $5.190 \mathrm{a}$ & $5.221 \mathrm{~A}$ \\
\hline PPFM Media foliar & $4.687 \mathrm{a}$ & $5.100 \mathrm{a}$ & $4.894 \mathrm{~A}$ & $5.140 \mathrm{a}$ & $5.339 \mathrm{a}$ & $5.239 \mathrm{~A}$ \\
\hline PPFM foliar & $5.460 \mathrm{a}$ & $4.571 \mathrm{a}$ & $5.016 \mathrm{~A}$ & $5.150 \mathrm{a}$ & $5.108 \mathrm{a}$ & $5.129 \mathrm{~A}$ \\
\hline Mean & $5.216 \mathrm{~A}$ & $5.024 \mathrm{~A}$ & ---------- & $5.180 \mathrm{~B}$ & $5.212 \mathrm{~A}$ & ---------- \\
\hline \multicolumn{7}{|c|}{ Phosphorus \% } \\
\hline Control & $0.360 \mathrm{a}$ & $0.290 \mathrm{a}$ & $0.325 \mathrm{~A}$ & $0.322 \mathrm{a}$ & $0.267 \mathrm{a}$ & $0.295 \mathrm{~A}$ \\
\hline PPFM Media foliar & $0.315 \mathrm{a}$ & $0.345 \mathrm{a}$ & $0.330 \mathrm{~A}$ & $0.323 \mathrm{a}$ & $0.326 \mathrm{a}$ & $0.325 \mathrm{~A}$ \\
\hline PPFM foliar & $0.341 \mathrm{a}$ & $0.362 \mathrm{a}$ & $0.352 \mathrm{~A}$ & $0.304 \mathrm{a}$ & $0.319 \mathrm{a}$ & $0.311 \mathrm{~A}$ \\
\hline Mean & $0.339 \mathrm{~A}$ & $0.332 \mathrm{~A}$ & ---------- & $0.317 \mathrm{~A}$ & $0.304 \mathrm{~A}$ & ---------- \\
\hline \multicolumn{7}{|c|}{ Potassium \% } \\
\hline Control & $1.636 \mathrm{a}$ & $1.661 \mathrm{a}$ & $1.649 \mathrm{~A}$ & $1.656 \mathrm{ab}$ & $1.587 \mathrm{ab}$ & $1.622 \mathrm{~B}$ \\
\hline PPFM Media foliar & $1.550 \mathrm{a}$ & $1.673 \mathrm{a}$ & $1.612 \mathrm{~A}$ & $1.558 \mathrm{~b}$ & $1.692 a b$ & $1.625 \mathrm{~B}$ \\
\hline PPFM foliar & $1.611 \mathrm{a}$ & $1.501 \mathrm{a}$ & $1.556 \mathrm{~A}$ & $1.573 \mathrm{~b}$ & $1.833 \mathrm{a}$ & $1.703 \mathrm{~A}$ \\
\hline Mean & $1.599 \mathrm{~B}$ & $1.612 \mathrm{~A}$ & --------- & $1.596 \mathrm{~B}$ & $1.704 \mathrm{~A}$ & --------- \\
\hline
\end{tabular}

Means followed by different letters are significantly different at $\mathrm{P} \leq 0.5$ level; Duncan's multiple range test.

\section{Potassium concentration in leaf}

Dipping the seedlings with PPFM gave the highest potassium concentration as compared with non-dipping ones.

Regarding the effect of foliar spray, the various tested plants varied significantly in potassium concentration, PPFM foliar spray gave the highest values of potassium concentration compared with the other studied foliar spray.

The interaction between dipping seedlings with PPFM and PPFM foliar spray induced the highest values of potassium concentration than the other combination treatments.

\section{Fruit Chemical Components}

Data presented in Table (3) show the influence of dipping seedlings in PPFM and foliar spray on chemical characteristics (total protein, total carbohydrates and ascorbic acid content) in fruit of eggplant in the two seasons (2014 and 2015).

\section{Total protein in fruit}

Dipping the seedlings in PPFM generally, gave the highest total protein as compared with the nondipping control.

As for the effect of foliar spray on total protein in fruit, the various tested plants varied insignificantly with all tested treatments.

The interaction between dipping seedlings with PPFM and PPFM media foliar spray showed the higher values of total protein in fruit than the other combination treatments.

\section{Total carbohydrates in fruit}

Dipping the seedlings in PPFM insignificantly affecting all other tested treatments. Also, the effect of foliar spray and the interaction with all tested treatments on total carbohydrates in fruit were insignificant.

\section{Ascorbic acid content in fruit}

Dipping the seedlings in PPFM has insignificant effect with all tested treatments.

Regarding the effect of foliar spray, the various tested plants varied significantly in Vitamin "C" content, PPFM foliar spray gave the highest values of vitamin $\mathrm{C}$ compared with the other studied foliar spray treatments.

The interaction with all tested treatments on Vitamin "C" content was insignificant.

\section{Yield and its Components}

Data presented in Tables (4 \& 5) show the influence of dipping seedlings with PPFM and foliar spray on yield characteristics (fruit length, fruit diameter, fruit number per plant, yield per plant and total yield) of eggplant in the two seasons (2014 and 2015). 
Table 3. Effect of pink pigmented facultative methylotrophic (PPFM) bacteria on total protein, total carbohydrates and vitamin C in fruit of eggplant, in the two seasons (2014/2015)

\begin{tabular}{|c|c|c|c|c|c|c|}
\hline Treatments & Control & $\begin{array}{l}\text { PPFM } \\
\text { dipping }\end{array}$ & Mean & Control & $\begin{array}{l}\text { PPFM } \\
\text { dipping }\end{array}$ & Mean \\
\hline & \multicolumn{3}{|c|}{-----------1 ${ }^{\text {st }}$ season----------- } & \multicolumn{3}{|c|}{-------------2nd season----------- } \\
\hline \multicolumn{7}{|c|}{ Total protein $(\mathrm{g} / 100 \mathrm{~g} \mathrm{DW})$} \\
\hline Control & $18.637 \mathrm{a}$ & $16.012 \mathrm{a}$ & 17.325 A & 19.629ab & $18.725 \mathrm{~b}$ & 19.177 A \\
\hline PPFM Media foliar & $22.138 \mathrm{a}$ & $24.675 \mathrm{a}$ & $23.406 \mathrm{~A}$ & $20.096 a b$ & $24.062 \mathrm{a}$ & $22.079 \mathrm{~A}$ \\
\hline PPFM foliar & $18.987 \mathrm{a}$ & $19.075 \mathrm{a}$ & $19.031 \mathrm{~A}$ & $19.629 a b$ & $20.767 a b$ & $20.198 \mathrm{~A}$ \\
\hline Mean & $19.921 \mathrm{~A}$ & $19.921 \mathrm{~A}$ & --------- & $19.785 \mathrm{~B}$ & $21.185 \mathrm{~A}$ & --------- \\
\hline \multicolumn{7}{|c|}{ Total carbohydrates (g/100g DW) } \\
\hline Control & $3.200 \mathrm{a}$ & $0.960 \mathrm{a}$ & $2.080 \mathrm{~A}$ & $2.627 \mathrm{a}$ & $1.133 \mathrm{a}$ & $1.880 \mathrm{~A}$ \\
\hline PPFM Media foliar & $2.540 \mathrm{a}$ & $2.020 \mathrm{a}$ & $2.280 \mathrm{~A}$ & $2.960 \mathrm{a}$ & $2.280 \mathrm{a}$ & $2.620 \mathrm{~A}$ \\
\hline PPFM foliar & $1.820 \mathrm{a}$ & $3.620 \mathrm{a}$ & $2.720 \mathrm{~A}$ & $2.000 \mathrm{a}$ & $2.147 \mathrm{a}$ & $2.073 \mathrm{~A}$ \\
\hline Mean & $2.520 \mathrm{~A}$ & $2.200 \mathrm{~A}$ & ---------- & $2.529 \mathrm{~A}$ & $1.853 \mathrm{~A}$ & ---------- \\
\hline \multicolumn{7}{|c|}{ Vitamin C (g/100ml) } \\
\hline Control & $0.200 \mathrm{a}$ & $0.100 \mathrm{a}$ & $0.150 \mathrm{~A}$ & $0.167 \mathrm{a}$ & $0.100 \mathrm{a}$ & $0.133 \mathrm{~B}$ \\
\hline PPFM Media foliar & $0.200 \mathrm{a}$ & $0.100 \mathrm{a}$ & $0.150 \mathrm{~A}$ & $0.133 \mathrm{a}$ & $0.100 \mathrm{a}$ & 0.117 B \\
\hline PPFM foliar & $0.100 \mathrm{a}$ & $0.200 \mathrm{a}$ & $0.150 \mathrm{~A}$ & $0.167 \mathrm{a}$ & $0.133 \mathrm{a}$ & $0.150 \mathrm{~A}$ \\
\hline Mean & $0.167 \mathrm{~A}$ & $0.133 \mathrm{~A}$ & ---------- & $0.156 \mathrm{~A}$ & $0.111 \mathrm{~A}$ & ---------- \\
\hline
\end{tabular}

Table 4. Effect of pink pigmented facultative methylotrophic (PPFM) bacteria on fruit length, fruit diameter, fruit number per plant, yield per plant and total yield of eggplant, in the two seasons (2014 and 2015)

\begin{tabular}{|c|c|c|c|c|c|c|}
\hline Treatments & Control & $\begin{array}{l}\text { PPFM } \\
\text { dipping }\end{array}$ & Mean & Control & $\begin{array}{l}\text { PPFM } \\
\text { dipping }\end{array}$ & Mean \\
\hline & \multicolumn{3}{|c|}{ 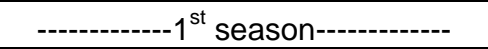 } & \multicolumn{3}{|c|}{ 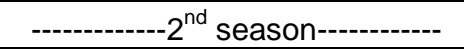 } \\
\hline \multicolumn{7}{|c|}{ Fruit length $(\mathrm{cm})$} \\
\hline Control & $15.4 a b$ & $14.38 \mathrm{bc}$ & $14.89 \mathrm{~A}$ & $15.02 a b$ & $14.62 \mathrm{c}$ & $14.82 \mathrm{~A}$ \\
\hline PPFM Media foliar & $14.14 \mathrm{C}$ & $15 \mathrm{abc}$ & $14.57 \mathrm{~A}$ & $14.49 \mathrm{c}$ & $14.56 \mathrm{c}$ & $14.52 \mathrm{~A}$ \\
\hline PPFM foliar & $14.27 \mathrm{c}$ & $15.69 \mathrm{a}$ & $14.98 \mathrm{~A}$ & $14.69 \mathrm{bc}$ & $15.08 \mathrm{a}$ & $14.89 \mathrm{~A}$ \\
\hline Mean & $14.6 \mathrm{~A}$ & $15.02 \mathrm{~A}$ & -------- & $14.73 \mathrm{~A}$ & $14.75 \mathrm{~A}$ & -------- \\
\hline \multicolumn{7}{|c|}{ Fruit diameter (mm) } \\
\hline Control & $29.47 a b$ & $28.94 b$ & $29.21 \mathrm{~A}$ & $30.36 a b$ & $30.01 \mathrm{~b}$ & $30.19 \mathrm{~A}$ \\
\hline PPFM Media foliar & $29.46 \mathrm{ab}$ & $30.36 \mathrm{a}$ & $29.91 \mathrm{~A}$ & 29.7 b & $29.82 b$ & $29.76 \mathrm{~A}$ \\
\hline PPFM foliar & $30.34 \mathrm{a}$ & $30.53 \mathrm{a}$ & $30.43 \mathrm{~A}$ & $30.44 \mathrm{ab}$ & $31.26 \mathrm{a}$ & $30.85 \mathrm{~A}$ \\
\hline Mean & $29.76 \mathrm{~A}$ & $29.94 \mathrm{~A}$ & -------- & $30.17 \mathrm{~A}$ & $30.36 \mathrm{~A}$ & -------- \\
\hline \multicolumn{7}{|c|}{ Fruit number per plant } \\
\hline Control & $27.21 \mathrm{~b}$ & $25.89 \mathrm{~b}$ & $26.05 \mathrm{~B}$ & $25.97 \mathrm{C}$ & $26.86 a b$ & $26.42 B$ \\
\hline PPFM Media foliar & $29.1 \mathrm{~b}$ & $30.36 \mathrm{~b}$ & 29.73 B & $29.64 a b$ & $27.12 b$ & $28.88 \mathrm{~B}$ \\
\hline PPFM foliar & $31.28 \mathrm{~b}$ & $34.83 \mathrm{a}$ & $33.06 \mathrm{~A}$ & $28.76 \mathrm{~b}$ & $31.85 \mathrm{a}$ & $30.3 \mathrm{~A}$ \\
\hline Mean & $28.86 \mathrm{~B}$ & $31.36 \mathrm{~A}$ & -------- & $28.12 \mathrm{~A}$ & $28.94 \mathrm{~A}$ & ------- \\
\hline
\end{tabular}


Table 5. Effect of pink pigmented facultative methylotrophic (PPFM) bacteria on yield per plant and total yield of eggplant, in the two seasons (2014 and 2015)

\begin{tabular}{|c|c|c|c|c|c|c|}
\hline Treatments & Control & $\begin{array}{l}\text { PPFM } \\
\text { dipping }\end{array}$ & Mean & Control & $\begin{array}{l}\text { PPFM } \\
\text { dipping }\end{array}$ & Mean \\
\hline & \multicolumn{3}{|c|}{------1 $1^{\text {st }}$ season-------- } & \multicolumn{3}{|c|}{ 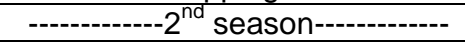 } \\
\hline \multicolumn{7}{|c|}{$\begin{array}{l}\text { Yield per plant }(\mathbf{k g}) \\
\end{array}$} \\
\hline Control & $3.99 \mathrm{~b}$ & $3.95 \mathrm{~b}$ & $3.97 \mathrm{~B}$ & $4.1 \mathrm{~b}$ & $3.97 \mathrm{~b}$ & $4.03 \mathrm{~B}$ \\
\hline PPFM Media foliar & $3.98 \mathrm{~b}$ & $4.13 \mathrm{~b}$ & $4.05 \mathrm{~B}$ & $4.13 \mathrm{~b}$ & $4.16 \mathrm{~b}$ & $4.14 \mathrm{~B}$ \\
\hline PPFM foliar & $4.23 \mathrm{~b}$ & $4.65 \mathrm{a}$ & $4.44 \mathrm{~A}$ & $4.245 b$ & $4.63 \mathrm{a}$ & $4.44 \mathrm{~A}$ \\
\hline Mean & $4.07 \mathrm{~A}$ & $4.24 \mathrm{~A}$ & ------ & $4.16 \mathrm{~A}$ & $4.25 \mathrm{~A}$ & ------- \\
\hline \multicolumn{7}{|c|}{ Total yield (ton/fed) } \\
\hline \multirow{3}{*}{$\begin{array}{l}\text { Control } \\
\text { PPFM } \\
\text { Media foliar } \\
\text { PPFM foliar } \\
\quad \text { Mean }\end{array}$} & $34.21 \mathrm{~b}$ & $33.89 \mathrm{~b}$ & $34.05 \mathrm{~B}$ & $35.15 \mathrm{~b}$ & $34.02 \mathrm{~b}$ & $34.58 \mathrm{~B}$ \\
\hline & $34.1 \mathrm{~b}$ & $35.36 \mathrm{~b}$ & 34.73 B & $35.38 \mathrm{~b}$ & $35.62 \mathrm{~b}$ & $35.5 \mathrm{~B}$ \\
\hline & $\begin{array}{l}36.28 \mathrm{~b} \\
34.86 \mathrm{~B}\end{array}$ & $\begin{array}{l}38.83 \mathrm{a} \\
36.36 \mathrm{~A}\end{array}$ & 38.066 A & $\begin{array}{l}36.39 \mathrm{~b} \\
\mathbf{3 5 . 6 4} \mathrm{A}\end{array}$ & $\begin{array}{c}38.7 \mathrm{a} \\
36.45 \mathrm{~A}\end{array}$ & $38.05 \mathrm{~A}$ \\
\hline
\end{tabular}

\section{Fruit length}

Dipping the seedlings in PPFM generally has insignificant effect with all tested treatments in both seasons.

The effect of foliar spray, the various tested plants varied insignificantly with all tested treatments on fruit length in both seasons.

The interaction between dipping seedlings with PPFM and PPFM foliar spray showed the highest fruit length as compared with that of the other combination treatments in both seasons.

\section{Fruit diameter}

Dipping the seedlings in PPFM has insignificant effect with all tested treatments in both seasons.

Regarding the effect of foliar spray, the various tested plants varied insignificantly with all tested treatments on fruit diameter in both seasons.

The interaction between dipping seedlings with PPFM and PPFM foliar spray induced the highest fruit diameter than the other combination treatments in both seasons.

\section{Fruit number per plant}

Dipping the seedlings in PPFM gave the highest fruit number as compared with the non-dipping control in the first season and there was nonsignificant effect in the second season.

However, PPFM foliar spray gave the highest value of fruit number compared with the other studied foliar spray treatments in both seasons.

The interaction between dipping seedlings in PPFM and PPFM foliar spray induced the highest fruit number as compared with the other combination treatments in both seasons.

\section{Yield per plant}

Dipping the seedlings in PPFM caused insignificant effect with all tested treatments in both seasons.

Regarding the effect of foliar spray, the different tested plants varied significantly in yield per plant, PPFM foliar spray gave the highest value of yield per plant compared with the other studied treatments in both seasons.

The interaction between dipping seedlings in PPFM and PPFM foliar spray showed the highest yield per plant than the other combination treatments in both seasons. These results are in harmony with those obtained by Verginer et al (2010).

\section{Total yield}

Dipping the seedlings in PPFM gave the highest total yield as compared with the non-dipping control in the first season while non-significant effect was observed in the second season.

The various tested plants varied significantly in total yield, PPFM foliar spray gave the highest value of total yield compared with the other studied foliar sprays in both seasons.

The interaction between dipping seedlings in PPFM and PPFM foliar spray showed the highest total yield than the other combination treatments in both seasons.

These results could be attributed to the stimulating effect of PPFM on the vegetative growth (Table 1). Also, PPFM can accelerate the rate of 
photosynthesis and decrease the rate of photorespiration (Lee et al 2006). These responses explain the biochemical changes in fruit composition because they affected all physiological and biochemical pathways which related to quality of pods.

\section{CONCLUSIONS}

It can be recommended to add PPFMs vaccine with eggplant seedlings Soma cultivars immediately before planting and repeated after 30 days of planting the seedlings around the crown area (20 liters /fed) and spraying PPFMs after 30, 60, 90 days of planting (20 liters / fed) to obtain the best yield and quality of eggplant in the field.

\section{REFERENCES}

A.O.A.C., 2000. Official Methods of Analysis, A.O.A.C. $15^{\text {th }}$ Ed. Washington, D.C. USA, pp. 490-510.

Brown, J. and Lilliland O., 1946. Rapid determination of potassium and sodium in plant material and soil extracts by flame photometric. Proc. Amer. Soc. Hort. Sci, 48, 341- 346.

Fall, R. and A. Benson, 1996. Leaf methanol, the simplest natural products from plants. Trends in Plant Science, 1, 296-301.

Galbally, I.E. and Kirstine W., 2002. The production of methanol by flowering plants and the global cycle of methanol. Journal of Atmospheric Chemistry, 43, 195-229.

Gout, E., Aubert S., Bligny R., Rebeille F., Nonomura A.R., Benson A.A. and Douce R., 2000. Metabolism of Methanol in Plant Cells. Carbon-13 Nuclear Magnetic Resonance Studies. Plant Physiology, 123, 287-296.

Iguchi H., Hiroya Y. and Yasuyoshi S., 2015. Interactions of methylotrophs with plants and other heterotrophic bacteria. Microorganisms 3, 137-151.

Jahan, R., 2013. Diversity of Methylobacterium Species Associated with New Zealand Native Plants. M.Sc. Thesis, University of Waikato. New Zealand, Chapter 1, 1-28.

James, C.S. 1995. Analytical chemistry of foods Blokie Academic, Professional, London, UK, pp. 53-62.

Koller, H.R., 1972. Leaf area-leaf weight relationships in the Soybean canopy. Crop Sci., 12(3/4), 180-183.

Lee, H.S., M. Choi, K.Y. Chung and S.A. TM, 2006. Physiological enhancement of early growth of rice seedlings (Oryza sativa L.) by production of phytohormone of N2-fixing methylotrophic isolates. Bio. Ferti. Soils, 42, 402-408.

Lidstrom, M.E., 2001. The aerobic methylotrophic bacteria. In $M$. Dworkin (eds.). pp. 223-244. The prokaryotes. Springer-Verlag, New York, USA.

Madhaiyan, M., Poonguzhali S., Senthilkumar M., S. Seshadri, H. Chung, J. Yang, S. Sundaram and Sa, T., 2004. Growth promotion and induction of systemic resistance in rice cultivar Co-47 (Oryza sativa L.) by Methylobacterium spp. Botanical Bulletin of Academia Sinica, 45, 315-324.

McTaggart, T., Beck D., U. Setboonsarng, N. Shapiro, Woyke T., Lidstrom M., M. Kalyuzhnaya and Chistoserdova L., 2015. Genomics of methylotrophy in gram-positive methylamine-utilizing bacteria. Microorganisms, 3, 94-112

Meena, K.K., Kumar M. and Kalyuzhnaya M.G., 2012. Epiphytic pink-pigmented methylotrophic bacteria enhance germination and seedling growth of wheat (Triticum aestivum) by producing phytohormone. Antonie van Leeuwenhoek, 101, 777-786.

Mène-Saffranè, L., Davoine C., Stolz S.; Majcherczyk P. and Farmer E.E., 2007. Genetic removal of tri-unsaturated fatty acids suppresses developmental and molecular phenotypes of an Arabidopsis tocopherol-deficient mutant. Whole-body mapping of malondialdehyde pools in a complex eukaryote. J. Biol. Chem., 282(49), 35749-35756.

Nadali, I., Paknejad F., Moradi F., Vazan S., Tookalo M., Al-Ahmad M.J. and Pazoki, A. 2010. Effects of methanol on sugar beet (Beta vulgaris). Australian Journal of Crop Science, 4(6), 398-401.

Omer, Z.S., Tombolini R., Broberg A. and Gerhardson B., 2004. Indole-3-acetic acid production by pink-pigmented facultative methylotrophic Bacteria. Plant Growth Regulation, 43, 93-96.

Pregl, E. 1945. Quantitative organic micro analysis. $4^{\text {th }}$ Ed. J. Chundril, London, UK, pp. 33129.

Radha, T.K., Savalgi V.P. and Alagawadi A.R., 2009. Effect of methylotrophs on growth and yield of soybean (Glycine max (L.) Merrill). Karnataka J. Agric. Sci., 22(1), 118-121.

Ramirez, I., Dorta F., Espinoza V., Jimenez E., Mercado A. and Cortes H.P.A., 2006. Effects 
of foliar and root applications of methanol on the growth of Arabidopsis, tobacco and tomato plants. Journal of Plant Growth Regulation, 25, 30-44.

Schmid-Siegert, E., Loscos J. and Farmer, E. E. 2012. Inducible malondialdehyde pools in zones of cell proliferation and developing tissues in Arabidopsis. J. Biol. Chem., 287(12), 8954-8962.

Snedecor, G.W. and W.G. Cochran, 1982. Statistical Methods. $7^{\text {th }}$ Ed. lowa State Univ., press, lowa, U.S.A, pp. 85-101.
Verginer, M., Siegmund B., Cardinale M., Muller H., Choi Y., Miguez C.B., Leitner, E. and Berg G., 2010. Monitoring the plant epiphyte Methylobacterium extorquens DSM 21961 by real-time PCR and its influence on the strawberry flavor. FEMS Microbiology Ecology, 74(1), 136-145.

Waller, R.A. and Duncan D.B., 1969. A Bayes rule for the symmetric multiple comparison problems. J. Amer. Static. Assoc., 64, 14851503. 



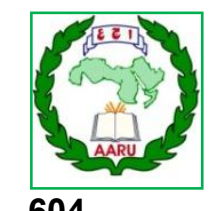

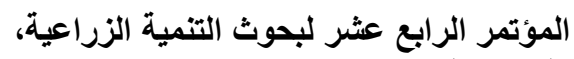

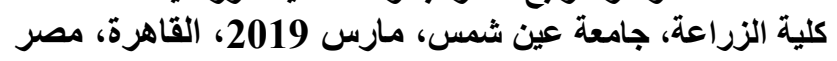

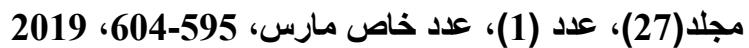

Website: http://strategy-plan.asu.edu.eg/AUJASCl/

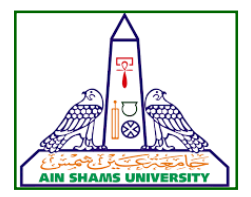

تأثر نمو وإنتاجية الباذنجان بالبكتريا القرمزية ميثيلية التغذية إختيارياً

[56]

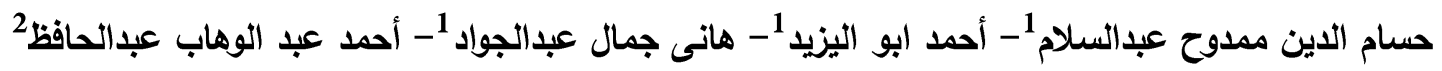

1.

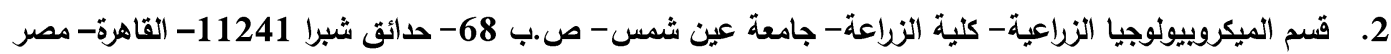

"Corresponding author: hossam1979@hotmail.com

Received 15 October, 2018,

Accepted 1 December, 2018

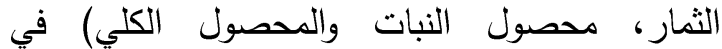

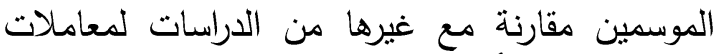

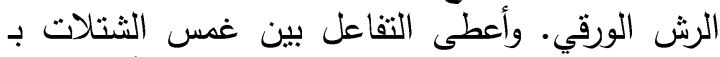

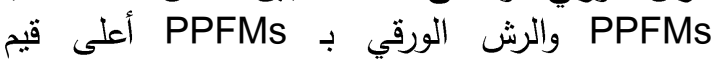

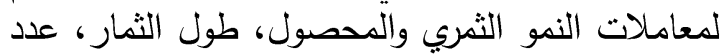

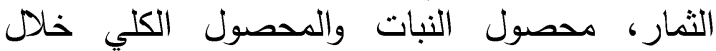
الموسمين. وبالنسبة للمحتوى الكيماوي للباذنجان

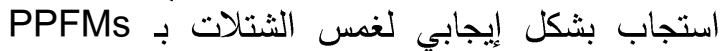
حيث أنه أعطى أعلى قيم في في تركيز النيتروجين

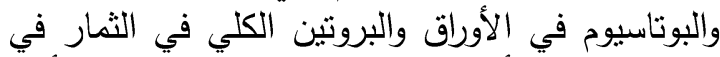

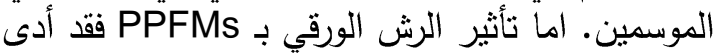

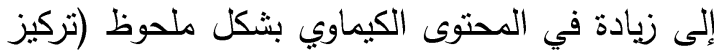

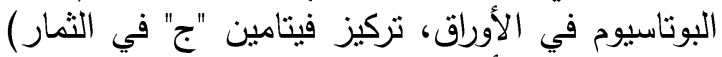

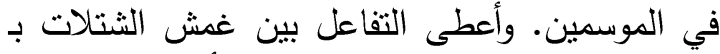
PPFMs والرش الورقي بـ PPFMs أعلى قيم لتركيز البوتاسيوم في الأوراق، خلال الموسمين.

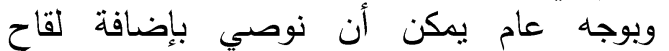

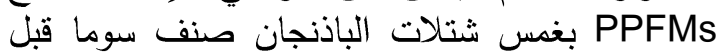

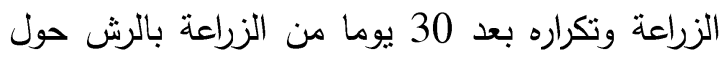

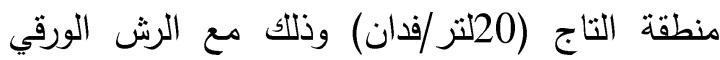
بلقاح PPFMs بعد 30، 60، 90 يوم من زراعة الترة الثتلات (20لتر/فدان) للحصول على أفضل أنتاجية

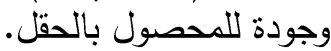

الكلمات الدالة: الباذنجان، البكتريا القرمزية ميثنيلية

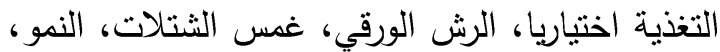

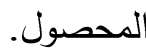

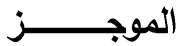

أجريت هذه الدراسة في المزرعة التجريبية بكلية

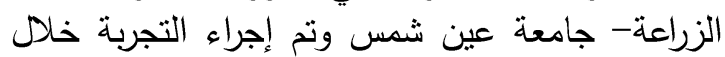

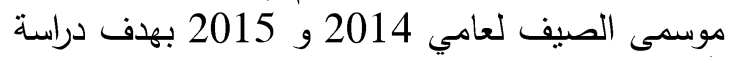
تأثير تلقيح منطقة الريزوسفير قبل الزراعة وكذلك الرشي دئ الورقي بالبكتريا القرمزية ميثيلية التغذية إختية التياريا

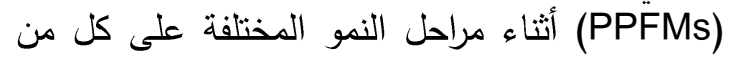

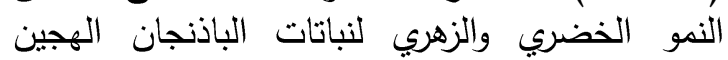

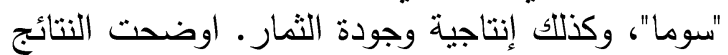

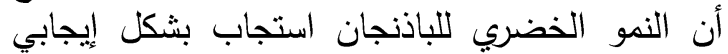
لغمس الثتلات بـ PPFMs حيث أنه أعطى أعلى قيم إني

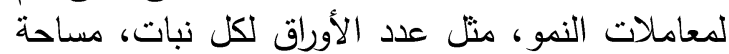

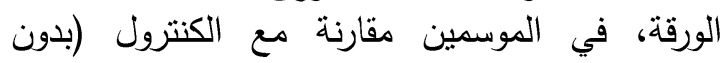

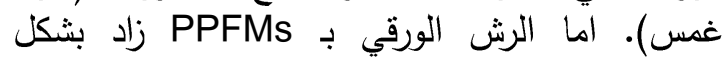
ملحوظ من نمو النبات (طول النبات، عدد الأوراق، الوزن الطازج للعرش، الوزن الطازج والجاف للأوراق، الأوراق،

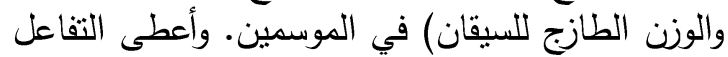

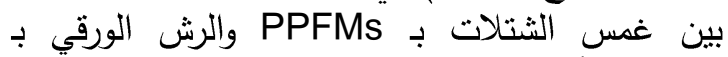

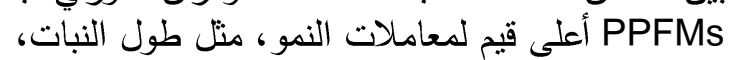

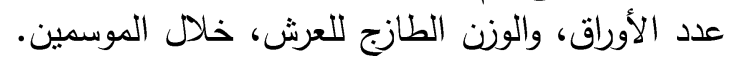

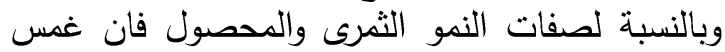

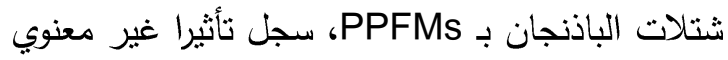

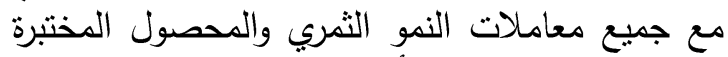
في كلا الموسمين. اما تأثير الرش الوبل الورقي بـ PPFMs

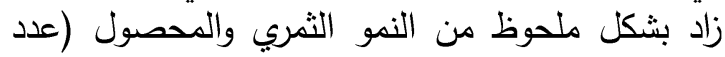

